\title{
Pengembangan Keterampilan Komunikasi Melalui Pelatihan Komunikasi Efektif di Sekolah Menengah Kejuruan
}

\author{
Yolanda Stellarosa ${ }^{1}$ dan Andre Ikhsano ${ }^{2}$ \\ 1, 2 Program Studi IImu Komunikasi, Institut Komunikasi dan Bisnis LSPR, Jakarta, Indonesia
}

\begin{abstract}
ABSTRAK
Berkomunikasi sering dianggap sesuatu yang simpel, sederhana dan tidak memerlukan suatu keterampilan khusus. Namun berbagai macam masalah komunikasi kerap kali muncul, mulai pada tataran makro di pemerintahan, di korporasi sampai pada level mikro di kehidupan sehari-hari. Berbagai masalah komunikasi sangat penting untuk dipahami lebih dalam agar pada sisi yang lain terus meningkatkan keterampilan berkomunikasi sehingga proses komunikasi berjalan dengan efektif. Terwujudnya komunikasi yang efektif tentu memerlukan ketrampilan komunikasi, salah satunya adalah untuk karier seseorang di segala bidang pekerjaan. Seseorang diharapkan dapat bekerjasama secara efektif dengan orang lain, menyajikan gagasan secara efektif dan lain sebagainya. Metode yang digunakan dalam kegiatan PKM adalah dengan melakukan penyuluhan dengan pihak mitra dengan peserta dari siswa-siswi sekolah menengah kejuruan. Penyuluhan dilakukan secara virtual di tengah pandemic covid 19 dengan mengedepankan simulasi atau roleplay pada peserta. Penyuluhan ini menunjukkan adanya antusianisme peserta dan juga peningkatan keterampilan berkomunikasi efektif sehingga dapat disarankan untuk dilanjutkan.
\end{abstract}

Kata kunci: komunikasi efektif; ketrampilan; masalah komunikasi

\begin{abstract}
Communication is often considered something simple and does not require any special skills. However, various kinds of communication problems often arise, starting at the macro level in government, in corporations to the micro level in everyday life. Various communication problems are very important to be understood more deeply in order to continue to improve communication skills so that the communication process runs effectively. The realization of effective communication certainly requires communication skills, one of which is for human careers in all fields of work. A person is expected to be able to cooperate effectively with others, present ideas effectively and so on. The method used in community service activities is to provide counseling with partners with participants from vocational high school students. Outreach is carried out virtually in the midst of the Covid 19 pandemic by prioritizing simulation or roleplay for participants. This counseling shows the enthusiasm of the participants and also increases in effective communication skills so that it can be suggested to continue.
\end{abstract}

Keywords: effective communication; skills; communication problems 


\section{PENDAHULUAN}

Komunikasi merupakan kunci sukses dalam pergaulan dan pekerjaan. Menurut Hovland, komunikasi pada dasarnya merupakan proses interaksi antar manusia melalui pertukaran informasi baik secara verbal maupun nonverbal untuk mengubah perilaku orang lain atau komunikan (Mulyana, 2017). Pada setiap aktivitas komunikasi umunya terdapat berbagai unsur yaitu adanya pengirim atau komunikator, penerima atau komunikan, pesan, terjadi proses encoding dan decoding, saluran atau media komunikasi, hambatan atau noise dalam penerimaan pesan komunikasi tersebut dan umpan balik yang diberikan (Liliweri, 2011).

Dalam hal penyampaian pesan oleh komunikator perlu diperhatikan pula bagaimana caranya agar pesan tersebut dapat tersampaikan dengan efektif sehingga mudah diterima dan dimengerti oleh penerima pesan atau komunikan. Misalnya saja dengan memilih media yang tepat untuk berkomunikasi. Akan tetapi komunikasi ini tidaklah mudah dan tidak selalu berjalan lancar. Seringkali komunikasi yang dilakukan mengalami hambatan atau distorsi. Oleh karena itu ketrampilan berkomunikasi menjadi sangat penting dalam menyelesaikan berbagai masalah komunikasi serta dalam upaya melakukan persuasi kepada komunikan.

Komunikasi sekilas terlihat sangat sederhana dan mudah, namun masalah komunikasi yang kerap terjadi di sekitar kita mengindikasikan bahwa komunikasi tidaklah dapat dikatakan mudah; dalam hal ini diperlukan keterampilan berkomunikasi dalam memahami komunikan dalam berkomunikasi. Pada tataran makro, masalah komunikasi dengan semangat penciptaan suatu narasi tunggal yang disampaikan oleh pemerintah kepada publik menjadi sangat penting. Koordinasi antar lini atau kementerian dan non kementerian menjadi kunci keberhasilan tata kelola komunikasi. Pada tataran korporasi, berbagai macam masalah komunikasipun kerap terjadi; baik komunikasi kepada eksternal meliputi kegiatan hubungan dengan media, komunitas, hubungan dengan investor serta pemerintah; sampai pada komunikasi internal seperti hubungan dengan karyawan dan sebagainya. Pada tataran mikro dalam berkomunikasi dalam kehidupan sehari-hari pun kerap terjadi masalah.

Dalam perspektif komunikasi, hambatan komunikasi dapat berbentuk: (1) fisik, misalnya saja tempat yang bising, suasana dan tempat saat komunikasi berlangsung dan sebagainya; (2) psikologis, unsur psikologis menjadi salah satu penyumbang timbulnya hambatan atau kegagalan komunikasi seperti persepsi, motivasi, hambatan mental yang mengganggu kelancaran pengiriman dan penerimaan pesan; (3) fisiologis, merupakan hambatan yang mencakup semua aspek fisik yang dapat mengganggu komunikasi; dan 4) semantik, merupakan hambatan yang muncul dalam bentuk kata-kata yang menganggu perhatian pengirim dan penerima terhadap suatu pesan, misalnya saja perbedaan bahasa atau penggunaan jargon atau istilah yang tidak dipahami komunikan (Orbe \& Bruess, 2005 dalam Liliweri, 2011). Merujuk pada penelitian yang dilakukan oleh Ayu dan Purba (2019) yang menyatakan bahwa proses komunikasi khususnya dalam mempersuasi seseorang tidak 
berhasil dilakukan karena faktor noise dimana kurangnya pemahaman komunikator akan keadaan sosial komunikan sehingga motivasi untuk pengembangan diri yang menjadi tujuan dari program yang dicanangkan tidak dapat berjalan baik.

Kegagalan komunikasi juga dapat terjadi salah satunya karena minimnya kemampuan mendengar lawan bicara kita. Mendengarkan adalah pekerjaan yang selama ini kurang mendapatkan perhatian, kita terlalu sibuk dengan berbicara. Setiap berkomunikasi kita selalu menunggu lawan bicara kita selesai bicara dan secepatnya mencoba untuk berbicara. Berbagai argumen, sanggahan dan bahan pembicaraan disiapkan sebanyak-banyaknya dalam benak kita ketika lawan bicara sedang berbicara. Mendengarkan bukanlah hanya sekedar masuknya stimulus berupa suara, bunyi dalam telinga kita. Mendengarkan adalah bagaimana mekanisme seluruh panca indra kita bekerja dan bersinergi dengan pikiran kita sehingga menghasilkan respon yang asertif pada lawan bicara kita; baik itu gesture, mimik muka, kontak mata dan lain sebagainya yang menunjukan begitu simpatinya kita pada lawan bicara (Devito, 2015).

Berdasarkan uraian di atas maka dapat dikatakan bahwa dalam berkomunikasi tidak ada suatu ketentuan yang baku agar pesan yang disampaikan dapat diterima dengan baik oleh komunikan. Komunikasi merupakan suatu seni, ilmu dan ketrampilan menyampaikan dan menerima informasi serta ide-ide dalam berbagai macam simbolnya. Tentu komunikasi terjadi dimana saja dan pada setiap orang, termasuk pada pelajar menengah atas khususnya pelajar sekolah menengah kejuruan.

Berbeda dengan sekolah menegah atas secara umum, sekolah menengah kejuruan adalah salah satu bentuk satuan pendidikan formal yang menyelenggarakan pendidikan kejuruan pada jenjang pendidikan menengah sebagai lanjutan dari SMP/MTs atau bentuk lain yang sederajat atau lanjutan dari hasil belajar yang diakui sama atau setara SMP/MTs. Sekolah menengah kejuruan bertujuan menyelenggarakan pendidikan yang menghasilkan lulusan yang terampil dan siap kerja. Hal ini mengacu pada Peraturan Menteri Pendidikan dan Kebudayaan RI No. 34 tahun 2018 tentang Standar Nasional Pendidikan Sekolah Menengah Kejuruan/Madrasah Aliyah Kejuruan, yang menyatakan bahwa sekolah menengah kejuruan merupakan pendidikan menengah yang mempersiapkan peserta didik terutama untuk bekerja dalam bidang tertentu (Kemdikbud, 2019).

Agar dapat siap memasuki dunia kerja, maka salah satu ketrampilan yang harus dimiliki oleh peserta didik sekolah menengah kejuruan adalah ketrampilan komunikasi. Ketrampilan komunikasi sangat diperlukan dalam pergaulan maupun pekerjaan. Dengan memiliki ketrampilan komunikasi maka diharapkan seseorang dapat bekerjasama dengan efektif, menyajikan gagasan secara efektif dan lain sebagainya. 
Sekolah Menengah Kejuruan (SMK) Tarakanita merupakan mitra dimana pengabdian kepada masyarakat dilakukan, berlokasi di Jakarta Selatan, didirikan pada tahun 1968. Sekolah yang berada dibawah naungan Yayasan Tarakanita ini dikelola oleh suster dari kongregasi cinta kasih Santo Carolus Borromeus. Kegiatan belajar di sekolah dilaksanakan lima hari dalam seminggu, baik teori maupun praktik. Untuk melengkapi penguasaan ketrampilan maka siswa/i SMK Tarakanita juga berkesempatan untuk melakukan praktik kerja diberbagai perusahaan selama 3 bulan, Praktik kerja ini dilakukan pada saat siswa/i berada pada kelas 12. Dalam mengikuti praktik kerja ini, siswa/i diharapkan mendapatkan pengalaman bekerja sesungguhnya, bertemu serta bergaul dengan banyak orang sebagai rekan kerja dan sebagainya. Hal ini yang dikatakan sebagai proses pembelajaran dalam hidup yang sebenarnya. Dengan dilakukannya praktik kerja serta mempersiapkan lulusan yang terampil dan siap kerja; maka pelatihan atau penyuluhan mengenai keterampilan berkomunikasi yang efektif menjadi penting bagi siswa/i sekolah menengah kejuruan ini, khususnya pada kelas 12 , menjelang para siswa/i tersebut memasui dunia kerja (Admin, 2020).

Tujuan kegiatan pengabdian kepada masyarakat ini adalah untuk memberikan pemahaman dan tentunya keterampilan dalam berkomunikasi, baik dalam kehidupan sehari-hari maupun untuk berkomunikasi secara profesional di dunia kerja nantinya. Kegiatan ini mencakup penyuluhan berbagai macam materi komunikasi praktis antara lain: (1) mengembangkan keterampilan komunikasi yang efektif; (2) mengembangkan kemampuan mendengarkan dengan empati dan merespon orang lain; dan (3) mengembangkan keterampilan perilaku komunikasi yang asertif. Diharapkan dengan kegiatan pengabdian kepada masyarakat di SMK Tarakanita ini peserta didik dapat mengembangkan keterampilan berkomunikasi di kehidupan sehari-hari dan di dunia kerja nantinya.

\section{METODOLOGI PELAKSANAAN}

Metode pelaksanaan ini menjelaskan cara atau metode yang digunakan dalam proses keseluruhan kegiatan pengabdian kepada masyarakat, mulai dari tahap pertama yaitu tahap persiapan atau pra-kegiatan; pada tahapan ini dilakukan koordinasi antara panitia pelasana penyuluhan dengan mitra, penentuan waktu pelaksanaan penyuluhan, persiapan materi dan hal teknis lainnya sehubungan dengan penyuluhan dilaksanakan secara daring. Tahapan kedua adalah tahap pelaksanaan. Tahap ini dimulai dari pengecekan ksiapan pembicara, moderator, host, pengecekan peserta dan pelaksanaan penyuluhan. Tahap ketiga adalah paska kegiatan yaitu mencakup evaluasi kegiatan dan pembuatan serta publikasi kegiatan PKM. Berikut adalah bagan alir kegiatan PKM yang menjelaskan tahapan dalam metode pelaksanaan kegiatan: 


\section{Gambar 1. Tahapan Kegiatan Pengabdian Kepada Masayarakat}



Kegiatan pengabdian kepada masyarakat dalam bentuk penyuluhan ini dilakukan secara daring karena pada tanggal pelaksanaan yaitu 11 September 2020, masih berada pada masa pandemi Covid 19 di Jakarta dan sesuai dengan Peraturan Gubernur No. 33 tahun 2020 tentang pelaksanaan pembatasan sosial berskala besar dalam menangani Covid 19 di wilayah DKI Jakarta. Walaupun dilakukan secara daring, kegiatan penyuluhan ini menerapkan mekanisme workshop dengan dilaksanakan simulasi secara daring untuk pengembangan keterampilan berkomunikasi yang efektif, praktik berkomunikasi secara asertif dan adanya penjelasan mekanisme penyuluhan.

\section{HASIL DAN DISKUSI}

Kegiatan pengabdian kepada masyarakat dilaksanakan secara daring melalu aplikasi Zoom pada hari Jumat, 11 September 2020, pukul 10.00 hingga 12.00 WIB berlokasi di SMK Tarakanita, Jalan Pulo Raya IV/17, Kebayoran Baru, Jakarta Selatan, DKI Jakarta. Sebanyak 60 siswa/i kelas 12 dari 3 program keahlian yaitu manajemen perkantoran, bisnis dan pemasaran serta akuntansi dan keuangan; serta dihadiri pula kepala sekolah, perwakilan yayasan Tarakanita dan guru pendamping.

Acara penyuluhan dibuka oleh host atau moderator dari SMK Tarakanita dengan memperkenalkan pembicara penyuluhan. Kepala sekolah membuka acara dengan memberikan sambutan yang menekankan pentingnya keterampilan dalam berkomunikasi. Selanjutnya acara penyuluhan sendiri dimulai oleh pembicara dengan pemberian pretest sederhana mengenai keterampilan komunikasi efektif, dan dilanjutkan dengan pemberian materi.

Materi dimulai oleh pembicara dengan menekankan bahwa siswa/i sekolah menengah kejuruan kelas 12 diharapkan memasuki dunia kerja secepatnya setelah lulus sekolah; berbeda dengan siswa SMU lainnya; walaupun tidak menutup kemungkinan adanya lulusan 
sekolah menengah kejuruan yang melanjutkan ke jenjang pendidikan tinggi sebelum masuk ke dunia kerja. Untuk itu diperlukan kesiapan mental dan keterampilan dalam bekerja, salah satunya keterampilan berkomunikasi efektif.

Materi selanjutnya berupa penjelasan mengenai pentingya keterampilan berkomunikasi; dimulai dari apa yang dimaksud dengan komunikasi sampai kepada mengapa komunikasi menjadi penting. Tentunya bicara mengenai komunikasi tidak terlepas dari adanya pertukaran suatu ide atau gagasan yang bertujuan untuk mengubah tingkah laku komunikan (Rogers dalam Mulyana, 2017). Komunikasi secara sekilas memang belum dipandang penting, karena setiap orang menganggap bahwa komunikasi itu dilakukan secara alamiah setiap hari, bahkan sejak lahir dan manusia berkomunikasi secara otodidak. Namun demikian tidak selalu setiap proses komunikasi dapat berjalan dengan baik, sering kali kita temui perbedaan penafsiran akan pesan yang disampaikan.

Masalah komunikasi dapat terjadi karena adanya perbedaan perilaku; akibat perbedaan latar belakang manusia, berupa berbedaan budaya, agama, latar belakang pendidikan, suku, gaya komunikasi, jabatan dan lain sebagainya. Hal ini merupakan penyumbang terjadinya perbedaan persepsi. Perbedaan persepsi inilah yang mengakibatkan terjadinya masalah komunikasi. Merujuk pada penelitian yang dilakukan oleh Yusuf (2020) menyatakan bahwa hambatan kerap kali muncul ketika terdapat perbedaan latar belakang budaya, seperti yang dialami oleh responden mahasiswa dalam penelitian tersebut. Hambatan komunikasi yang ditemui lebih kepada hambatan dari segi fisik, budaya, persepsi, motivasi, pengalaman, emosi, bahasa dan lain sebagainya.

Pada saat penjelasan mengenai pentingnya komunikasi dan hambatan yang ditimbulkan dri proses komunikasi, pembicara menampilkan materi berupa powerpoint yang menggambarkan terjadinya perbedaan persepsi akibat perbedaan perilaku atau behaviour, tingkat Pendidikan, pengalaman, kedudukan dan sebagainya.

Gambar 2. PPT pembicara berbagai macam akibat masalah komunikasi

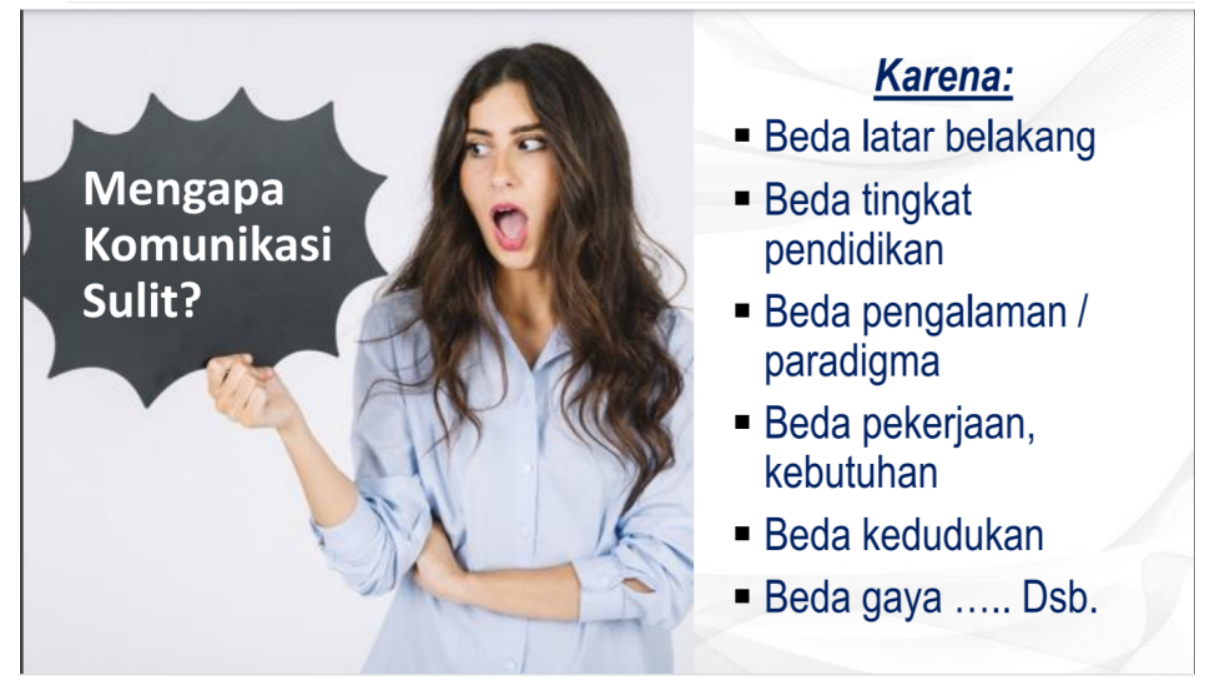


Dijelaskan pula terdapat unsur-unsur komunikasi, yang terdiri dari 1). Komunikator; bisa seorang individu, kelompok, organisasi maupun negara. 2). Pesan; yakni apa yang akan disampaikan oleh komunikator kepada komunikan; 3). Media komunikasi dan 4). komunikan, yaitu orang atau kelompok atau organisasi yang menerima pesan dari komunikator serta 5). Feedback (Mulyana, 2017). Komunikator adalah penyampai pesan atau pihak yang memulai komunikasi. Komunikator menjadi sangat penting dalam proses komunikasi. Terkadang dalam proses komunikasi, kita melihat siapa komunikatornya; tidak hanya melihat substansi pesannya. Untuk itu kredibiltas komunikator menjadi aspek penentu, komunikator wajib meningkatkan kredibilitasnya, unsur keahlian, pengalaman, pendidikan dan dapat dipercaya menjadi kunci terciptanya kredibilitas (Hasmawati, 2020).

Unsur pesan dalam proses komunikasi merupakan hal yang utama, terlebih bagaimana konsep atau strategi dan taktik penyampaian pesan yang buat. Media komunikasi menyangkut media-media apa saja yang tepat digunakan untuk menyampaikan suatu pesan. Terdapat kelebihan dan kekurangan dari masing-masing media, khususnya pada saat ini media yang sering digunakan adalah media digital. Media digital terdiri dari WhatsApp Facebook, Instagram, YouTube, website dan berbagai macam media digital lainnya.

Komunikan adalah penerima pesan, baik orang atau kelompok maupun organisasi. Dalam materi yang disampaikan pembicara, penting untuk dapat memahami dan memetakan penerima pesan. Seorang komunikator harus mengetahui siapa komunikannya; apa jenis kelaminnya, usia, ekonomi, sosial, budaya, politik dan lain sebagainya. Pemahaman ini akan menentukan pembuatan srategi komunikasi yang efektif. Untuk itu pembicara dalam penyuluhan ini menekankan adanya riset sederhana terlebih dahulu mengenai siapa komunikannya atau target khalayak sebelum kita melakukan komunikasi. Kita kenal dalam bahasa marketing disebut dengan market research. Dari unsur komunikator, pesan, media komunikasi dan komunikan yang sudah dipahami dan dipetakan dengan baik maka dapat diprediksi hasil pesan komunikasinya. Respon atau tanggapan dari komunikan apakah sesuai dengan yang kita harapkan atau tidak.

Berbagai macam pendalaman materi disampaikan oleh pembicara yang mengerucut pada bagaiman menciptakan komunikasi yang efektif melalui lima hukum komunikasi yang produktif, yaitu (1) respect; (2) empathy; (3) audible; (4) clarity; dan (5) humble (Fourianalistyawati, 2012). Respect mengacu pada sifat dasar manusia yang ingin dihargai. Dalam hal ini menghargai setiap individu yang menjadi sasaran pesan dari komunikator. Jika komunikasi dilakukan dengan sikap saling menghargai dan menghormati maka akkan tercipta kerjasama yang baik serta meningkatkan efektifitas dalam pekerjaan yang nantinya akan segera dimasuki oleh para lulusan sekolah menengah kejuruan ini. 
Empati merupakan kemampuan individu untuk dapat menempatkan diri pada situasi atau kondisi yang dihadapi orang lain. Utuk memiliki sikap empati maka harus memiliki kemampuan untuk mendengar atau mengerti terlebih dahulu, seperti mendengarkan rekan sekerja, teman dan orang lain di sekitar kita. Hukum komunikasi yang produktif ketiga adalah audible, yaitu pesan yang disampaikan oleh komunikator dapat didengarkan atau dimengerti dengan baik oleh komunikan. Agar pesan dapat dimengerti dan diterima dengan baik oleh komunikan maka suatu pesan harus memenuhi unsur clarity; dan untuk menghasilkan komunikasi yang efektif dan produktif maka diperlukan sikap humble yaitu sikap rendah hati. Tentunya lima hukum komunikasi produktif ini yang harus ada dalam diri setiap individu khususnya adalah para siswa/i kelas 12 SMK Tarakanita sebagai bekal untuk masuk ke dalam lingkungan baru yaitu lingkungan pekerjaan.

Gambar 3. PPT Lima Hukum Komunikasi yang produktif

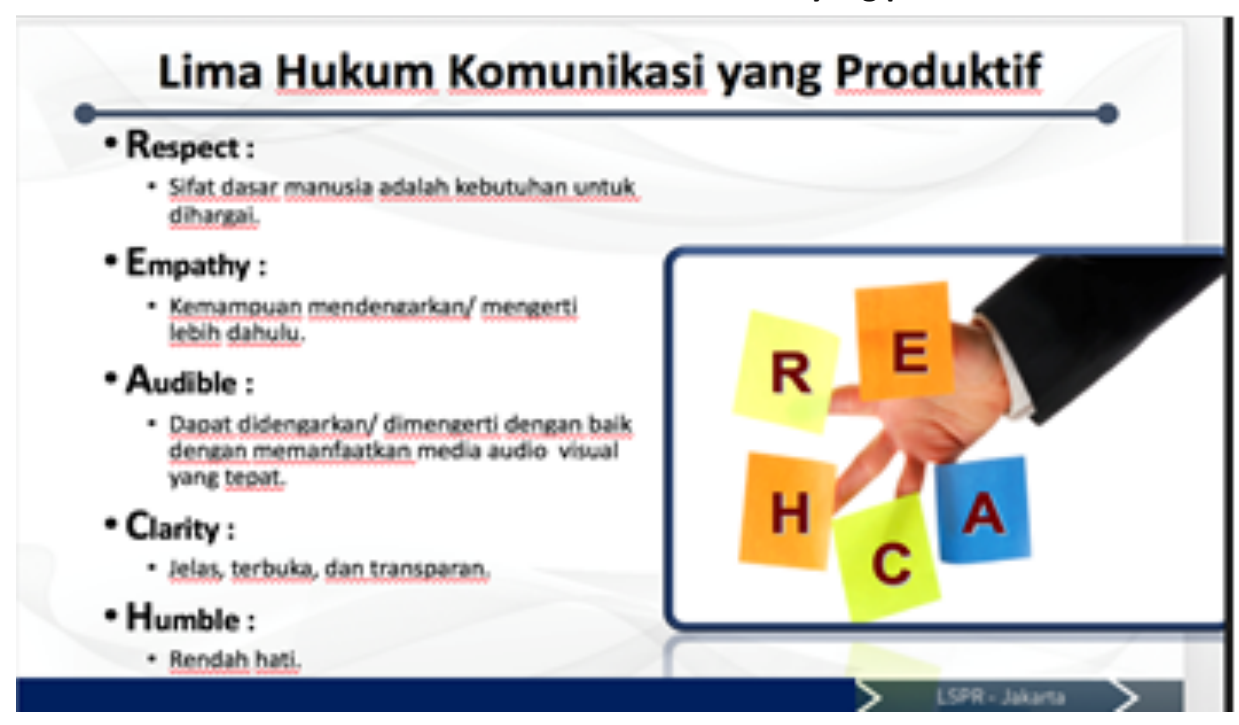

Membuat para peserta lebih memahami unsur psikologi komunikasi dengan menekankan pentingnya memuliakan manusia melalui komunikasi. Pada pertengahan penyuluhan, pembicara menekankan pentingnya mendengarkan sebagai bagian utama dalam berkomunikasi. Mendengarkan tentunya berbeda dengan mendengar. Mendengarkan merupakan proses aktif menerima rangsangan; tidak sekedar membutuhkan telinga saja tetapi juga pemusatan pikiran dan hati (Wood, 2013).

Mendengarkan secara aktif dan efektif berupa mencari kejelasan dari apa yang dibicarakan, menghindari asumsi-asumsi sepihak yang timbul, melakukan parafrase sebagai bentuk respon terhadap apa yang didengarkan, selain itu fokus pada lawan bicara, gesture yang tepat sebagai bentuk komunikasi nonverbal. Mendengarkan merupakan materi yang terkesan sederhana namun sangat penting dalam upaya untuk menghargai lawan bicara sehingga menunjukkan antusiasme kita. Contoh dari antusiasme seseorang dapat ditunjukkan dari screenshoot keantusiasan peserta. 


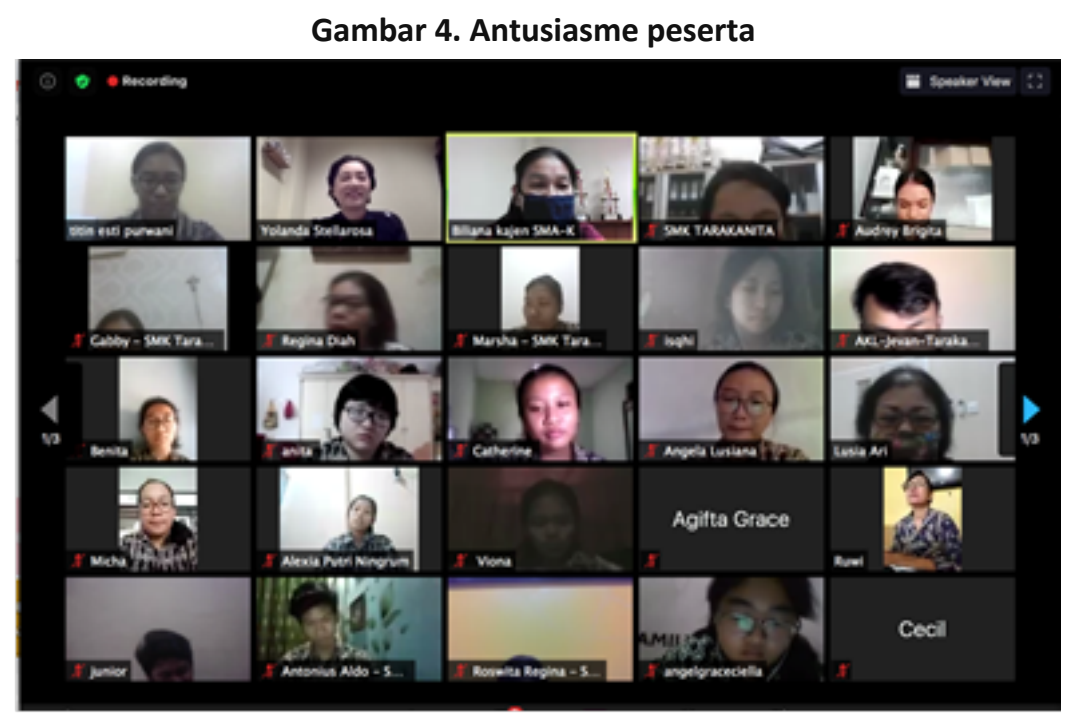

Menjelang akhir penyuluhan, pembicara mengajak peserta siswa/i SMK Tarakanita untuk melakukan simulasi berupa roleplay dalam berkomunikasi yang efektif. Kita ketahui bahwa berkomunikasi yang efektif juga ditentukan oleh pendekatan perilaku komunikasi, yaitu (1) submisif (non asertif), yaitu seseorang yang menunjukkan rendah diri sehingga dalam berinteraksi pun selalu disertai kekhawatiran dan kekecewaan pada diri sendiri; (2) agresif, dalam berkomunikasi umumnya terkesan superioritas, mendominasi dan tidak ada respek pada orang lain; dan (3) asertif, dalam berkomunikasi umumnya respek terhadap diri sendiri dan orang lain serta mampu mengkomunikasikan kebutuhan, keinginan dan perasaannya (Kranz \& Frauen dalam Utaminingtyas, 2019). Dalam perilaku berkomunikasi, perilaku asertif inilah yang harus terus diasah.

Dalam melakukan roleplay dibentuk kelompok dimana setiap kelompok terdiri dari tujuh sampai dengan delapan peserta; didistribusikan mengenai peran masing-masing dalam roleplay sebagai berikut:

Tabel 1. Mekanisme Roleplay Peserta

\begin{tabular}{|c|l|l|}
\hline PESERTA & \multicolumn{1}{|c|}{ KEGIATAN } & \multicolumn{1}{c|}{ DURASI } \\
\hline 1 & $\begin{array}{l}\text { Komunikator } \\
\text { a) Menceritakan kehidupan singkatnya. Misalnya: kehidupan } \\
\text { di sekolah, rumah, travelling, dll } \\
\text { b) Memberikan evaluasi dan menentukan siapa yang paling } \\
\text { menyimak }\end{array}$ & 10 menit \\
\hline 2 & $\begin{array}{l}\text { Komunikan } \\
\text { c) Mendengarkan, merespon, menanggapi pembicaraan }\end{array}$ & 10 menit \\
\hline 3 & $\begin{array}{l}\text { a) Mendengarkan, menyimak } \\
\text { b) Melaporkan aspek substansi pesan komunikator dan } \\
\text { komunikan }\end{array}$ & $\begin{array}{l}\text { Melaporkan 2 } \\
\text { menit }\end{array}$ \\
\hline 4 & $\begin{array}{l}\text { a) Mendengarkan, menyimak } \\
\text { b) Melaporkan aspek nonverbal komunikator dan komunikan }\end{array}$ & $\begin{array}{l}\text { Melaporkan 2 } \\
\text { menit }\end{array}$ \\
\hline
\end{tabular}




\begin{tabular}{|c|l|l|}
\hline 5 & $\begin{array}{l}\text { a) Mendengarkan, menyimak } \\
\text { b) Melaporkan aspek substansi pesan komunikator dan } \\
\text { komunikan }\end{array}$ & $\begin{array}{l}\text { Melaporkan 2 } \\
\text { menit }\end{array}$ \\
\hline 6 & $\begin{array}{l}\text { a) Mendengarkan, menyimak } \\
\text { b) Melaporkan aspek nonverbal komunikator dan komunikan }\end{array}$ & $\begin{array}{l}\text { Melaporkan 2 } \\
\text { menit }\end{array}$ \\
\hline $7 \& 8$ & Observasi jalannya roleplay & $\begin{array}{l}\text { Melaporkan 2 } \\
\text { menit }\end{array}$ \\
\hline
\end{tabular}

Dari kegiatan roleplay ini dari delapan kelompok yang telah ditentukan, maka setelah dievaluasi dengan mengedepankan terjadinya komunikasi yang efektif melalui kegiatan mendengar secara aktif maka dapat disimpulkan sebagai berikut:

Tabel 2. Aspek Penilaian Roleplay

\begin{tabular}{|c|c|c|c|}
\hline \multirow{2}{*}{ Kelompok } & \multicolumn{3}{|c|}{ Aspek Penilaian } \\
\cline { 2 - 4 } & $\begin{array}{c}\text { Fokus Pada } \\
\text { Lawan Bicara }\end{array}$ & $\begin{array}{c}\text { Nonverbal } \\
\text { Perilaku Asertif }\end{array}$ & $\begin{array}{c}\text { Pemahaman } \\
\text { Substansi Pesan }\end{array}$ \\
\hline Kelompok 1 & Baik & Baik & Baik Sekali \\
\hline Kelompok 2 & Baik & Cukup Baik & Baik \\
\hline Kelompok 3 & Baik & Baik & Baik Sekali \\
\hline Kelompok 4 & Cukup Baik & Cukup Baik & Baik \\
\hline Kelompok 5 & Baik Sekali & Baik & Baik \\
\hline Kelompok 6 & Baik Sekali & Baik & Baik Sekali \\
\hline Kelompok 7 & Baik & Baik & Baik Sekali \\
\hline Kelompok 8 & Baik Sekali & Baik &
\end{tabular}

Hasil dari kegiatan roleplay ini secara umum baik, terlihat dengan dominasi pada kategori baik dan baik sekali. Namun demikian dapat kita lihat lebih detail aspek yang perlu dikembangkan adalah aspek nonverbal perilaku berkomunikasi asertif. Hal ini tentu dapat dipahami bahwa pelaksanaan pengabdian ini dilakukan secara virtual, walaupun nonverbal masih dapat dilakukan namun tidak terlalu optimal sehingga aspek nonverbal menjadi hal yang perlu diperhatikan. Komunikasi asertif tentu melibatkan banyak perilaku yang berbeda baik secara verbal maupun nonverbal atau bahasa tubuh, yang perlu terus dilatih dan dipraktekan sehingga nantinya dapat menunjukkan kualitas dan kemampuan berkomunikasi yang positif.

Pada akhir penyuluhan, peserta juga diberikan kesempatan bertanya, berdiskusi dengan pembicara, waktu yang diberikan oleh panitia sebesar tigapuluh menit, namun peserta yang antusias bertanya sebanyak sepuluh peserta sehingga waktu yang telah ditentukan ditambah menjadi sepuluh menit untuk mengakomodasi pertanyaan peserta. 


\section{SIMPULAN DAN SARAN}

Kegiatan pengabdian kepada masyarakat ini dapat disimpulkan memenuhi tujuan yaitu mengembangkan keterampilan berkomunikasi efektif peserta, yatu siswa kelas 12 SMK Tarakanita Jakarta, yang terdiri dari 60 peserta; melalui mendengarkan dengan empati serta berperilaku komunikasi yang asertif. Materi penyuluhan ini bermanfaat dan mampu mengembangkan kemampuan keterampilan komunikasi efektif, sehingga dapat dilakukan dikemudian hari dengan waktu yang lebih banyak dan materi komunikasi efektif yang lebih menambah simulasi atau roleplay pada peserta penyuluhan yang sama. Untuk pendalaman materi maka dapat diberikan materi public speaking, event management, how to handle media digital? dan lain sebagainya untuk menambah keterampilan teknis berkomunikasi para siswa/i SMK Tarakanita, sehingga dapat lebih siap lagi untuk masuk dalam dunia kerja selulus dari sekolah menengah kejuruan ini.

Kegiatan ini juga dapat disimpulkan sangat bagus dilakukan dan bermanfaat, apalagi di tengah pandemi Covid-19 dimana para siswa lebih banyak beraktifitas di rumah. Dengan adanya beragam kegiatan yang positif seperti penyuluhan ini dapat mengisi waktu mereka dengan materi-materi yang berguna untuk pengembangan diri dan tetap dapat produktif di masa pandemi.

\section{Ucapan Terima Kasih}

Kegiatan penyuluhan ini dapat terselenggara berkat inisiatif dari SMK Tarakanita; sehingga penulis patut menyampaikan penghargaan dan ucapan terima kasih kepada pimpinan SMK Tarakanita beserta jajarannya selaku institusi dan juga kepada panitia acara. Penulis juga mengucapkan terima kasih kepada LPPPM Institut Komunikasi dan Bisnis LSPR atas dukungannya kepada penulis dalam melakukan program pengabdian kepada masyarakat ini. 


\section{DAFTAR PUSTAKA}

Ayu, S.M \& Purba, C.A. (2019). Komunikasi Persuasif Pekerja Sosial Dalam Proses Adaptasi Imigran Anak Tanpa Pendamping di Indonesia. Communicare: Journal of Communication Studies, 4(2), 79-90. https://doi.org/10.37535/101004220175

Admin. (2020, Mei 19). Sejarah SMK Tarakanita. SMK TARAKANITA JAKARTA. http://smkjkt.tarakanita.sch.id/page/sejarah-sekolah

Devito, J.A. (2015). The Interpersonal Communication Book (14th Ed.). Pearson Education Limited.

Fourianalistyawati, E. (2012). Komunikasi Yang Relevan dan Efektif Antara Dokter dan Pasien. Jurnal Psikogenesis, 1(1), 82-87. https://doi.org/10.24854/jps.v1i1.37

Kemdikbud. (2019). Standar Nasional Pendidikan Sekolah Menengah Kejuruan/Madrasah Aliyah Kejuruan. Direktorat Sekolah Menengah Kejuruan. Kementerian Pendidikan dan Kebudayaan Republik Indonesia. http://smk.kemdikbud.go.id/konten/4125/standar-nasional-pendidikan-smk-danmak

Liliweri, A. (2011). Komunikasi Serba Ada Serba Makna. Kencana Predana Media Group

Mulyana, D. (2017). IImu Komunikasi Suatu Pengantar. Remaja Rosdakarya.

Hasmawati, F. (2020). Karakteristik Komunikator Efektif dalam Komunikasi Antar Pribadi. Jurnal Komunikasi Islam dan Kehumasan, 4(2), 69-95. https://doi.org/10.19109/jkpi.v4i2.7315

Utaminingtyas, R.R.B. (2019). Pengembangan Aspek Non Verbal Perilaku Asertif Dengan Assertive Training. Jurnal Admisi dan Bisnis, 20(2), 117-126. http://dx.doi.org/10.32497/ab.v20i2.1649

Wood, J.T. (2013). Komunikasi Interpersonal: Interkasi Keseharian (6th ed). Penerbit Salemba Humanika.

Yusuf. S. (2020). Hambatan Komunikasi Antarbudaya (Studi Kasus pada Mahasiswa Program Studi Magister Ilmu Komunikasi Gadjah Mada Angkatan 2019). Komunikologi Jurnal Pengembangan Ilmu Komunikasi dan Sosial, 4(1), 39-52. http://dx.doi.org/10.30829/komunikologi.v4i1.6745 